\title{
ROBUSTNESS EVALUATION OF THE CHROMATOGRAPHIC DETERMINATION OF VALSARTAN IN PHARMACEUTICALS
}

\author{
OK. Peleshok, O. Dutchak, Fatma Abdelmalek Mohamed \\ I. Horbachevsky Ternopil National Medical University
}

SUMMARY. The robustness of an analytical procedure is a measure of its capacity to remain unaffected by small, but deliberate variations in method parameters and provides an indication of its reliability during normal usage.

The aim of the study - to evaluate the rubustness of HPLC determination of valsartan in tablets using Youden's test.

Material and Methods. An efficient method to assess the robustness of analytical methodsis by Youden's test, by means of an experiment design which involves seven analytical parameters combined in eight tests. In the recent studies, we assessed the robustness of a chromatographic method to quantify valsartan in tablets using Youden's test.

Results. The experimental design approach (design of experiment) is the method of simultaneous investigation of the influence of several factors on robustness of the method using a certain plan (matrix) of experiments. By using the Youden's test criteria, HPLC method showed to be greatly robust concerning valsartan content, at the introduction of variation in seven analytic parameters. This was done in order to make analytical scientists more successful and businesses more profitable and productive.

Conclusion. Youden's test proved to be an efficient and helpful tool for the robustness evaluation for assay of valsartan by HPLC. Youden's test can be applied successfully for the robustness evaluation in validation process of analytical methods.

KEY WORD: valsartan; high-performance liquid chromatography; robustness; quantitative analysis; Youden's test.

Introduction. Valsartan (Fig. 1) is chemically described as (2S)-3-methyl-2-[pentanoyl-[[4-[2-(2H-tetrazol-5-yl)phenyl]phenyl]methyl]amino]butanoic acid. Valsartan is an orally active nonpeptide triazole-derived antagonist of angiotensin (AT) II with antihypertensive properties. Valsartan selectively and competitively blocks the binding of angiotensin II to the AT1 subtype receptor in vascular smooth muscle and the adrenal gland, preventing AT II-mediated vasoconstriction, aldosterone synthesis and secretion, and renal reabsorption of sodium, and resulting in vasodilation, increased excretion of sodium and water, a reduction in plasma volume, and a reduction in blood pressure. Therefore, analytical methods for their separation and quantification in pharmaceutical formulations and inhuman plasma are desirable for quality control and therapeutic drug monitoring, respectively. Several techniques have been reported in the literature for the determination of valsartan individually in pharmaceutical dosage forms or human serum samples such as spectrophotometry, high performance liquid chromatography-tandem mass spectrometry (LC-MS/MS), HPLC methods with photometric, fluorimetric detection coupled with mass spectrometry as well as the derivative UV-spectrophotometry methods [1-18].<smiles>CCCCC(=O)N(Cc1ccc(-c2ccccc2-c2nn[nH]n2)cc1)C(C)C</smiles>

Fig. 1. Chemical structure of valsartan.

The generally accepted definition of the term "robustness" with respect to analytical methods is specified in ICH Q2 (R1): "the robustness of an analytical procedure is a measure of its capacity to remain unaffected by small, but deliberate variations in method parameters and provides an indication of its reliability during normal usage". ICH Q2 (R1) also states that the robustness assessment "should show the reliability of an analysis with respect to deliberate variations in method parameters. If measurements are susceptible to variations in analytical conditions, the analytical conditions should be suitably 
Огляди літератури, оригінальні дослідження, погляд на проблему, випадок з практики, короткі повідомлення controlled or a precautionary statement should be included in the procedure. One consequence of the evaluation of robustness should be that a series of system suitability parameters (e.g., resolution test) is established to ensure that the validity of the analytical procedure is maintained whenever used" [19-21].

The aim of the study was to evaluate the robustness of HPLC (High-Performance Liquid Chromatography) method for the quantitation of valsartan, using Youden's test, and determine the analytical parameters that present greater influence in the final results of the analysis.

Material and Methods. Valsartan (purity $99.9 \%$ ) was purchased from Jubilant Generics Limited (India). The methanol used in experiments was HPLC gradient grade and potassium dihydrogen phosphate was of Ph.Eur.reagent grade and purchased from Merck Darmstdat, Germany. Analytical Balance Mettler Toledo MPC227, pH-metter Metrohm 827, demineralized water from TKA Micro system, with final conductivity less than $0.05 \mu \mathrm{S} / \mathrm{cm}$. IKA orbital shaker KS4000i was used for sample agitation. The nylon and regenerated cellulose RC $0.45 \mathrm{um}$ syringe filters were purchased from Agilent Technologies.

Dionex Ultimate 3000 UHPLC system controlled by Chromeleon version 6.80, composed of quaternary LPG pump ultimate 3000 , autosampler ultimate 3000 , ultimate 3000 column compartment, four channel UV-Vis detector ultimate 3000 RS. Shimadzu Nexera XR UPLC system with LPG Quaternary Pump LC-20AD with degasser DGU-20A5R, Autosempler SIL-20AC, PDA detector M20-A, Column Oven and Controller CBM-20A controlled by Lab Solutions version 5,97. The used column Zorbax C8 $(4.6 \mathrm{~mm}$ i.d. $X$ $150 \mathrm{~mm}, 5 \mu \mathrm{m})$, purchased from Sigma-Aldrich Supelco. The optimum mobile phase composition was composed of methanol and $25 \mathrm{mM}$ solution potassium dihydrogen phosphate $\mathrm{pH} 7.3$ (55:45, V/V), pumped with $1.0 \mathrm{~mL} / \mathrm{min}$ at $40^{\circ} \mathrm{C}$ set temperature of column oven, with UV detector set to $225 \mathrm{~nm}$ wavelength. Analyses performed on column Zorbax C8 (4.6 mm i.d. X $150 \mathrm{~mm}, 5 \mu \mathrm{m})$ [22].

Sample preparation

Twelve tablets of each preparation were studied to obtain statistically significant results. The tablets with declared contents of $80 \mathrm{mg}$ valsartan were purchased from local drug store, pharmacy. The tablets were put in $100 \mathrm{~mL}$ measuring flasks and dissolved in $50 \mathrm{~mL} 50 \% \mathrm{v} / \mathrm{v}$ methanol, ultrasound crushed and treated for 2 minutes and shaked $15 \mathrm{~min}$ with orbital shaker. After that measuring flasks were filled to mark for $100 \mathrm{~mL}$, the final concentration was $0.8 \mathrm{mg} / \mathrm{mL}$ for valsartan. Samples were filtered with RC $0.45 \mathrm{um}$ syringe filters and injected.

Results and Discussion. In the investigation of the robustness of analytical methods, one of two

main methods are frequently used: The "One-factora-time" method (the alternative name is "One-variable-at-a-time procedure") is a concurrent study of the influence of only one factor on the robustness of an analytical method with fixed values of all other factors at a time. The experimental design approach (design of experiment) is the method of simultaneous investigation of the influence of several factors on robustness of the method using a certain plan (matrix) of experiments [23].

The robustness evaluation of HPLC method for valsartan quantitation was performed using the method proposed by Youdene Steiner. Seven analytical parameters were selected and small variations were induced in the nominal values of the method. Then, eight runs were performed with an aim to determine the effect of each parameter in the final result. The seven analytical parameters employed, as well as the introduced variations are demonstrated at table 1 . The analytical conditions at the nominal values are represented by capital letters and the conditions with the small variation are represented by lowercase letters [24-26].

The seven parameters and its respective variations were combined in eight assays or chromatographic runs, performed in a random order. Table 2 demonstrates the factorial combination of the parameters for the Youden's test. The analyses results are shown by letters from $s$ to $z$. Hence, when combination 1 was assayed, the obtained result was $s$. When combination 2 was assayed, the obtained result was $t$, and so successively.

In each combination, three injections of each sample and standard solutions were carried out, at the work concentration. After the alteration of chromatographic column or mobile phase composition, there was a waiting of 30 min for system stabilization. The evaluated results in each combination were peak area, retention time (Rt), tailing factor $(T)$, theoretical plates number $(\mathrm{N})$ and valsartan content.

For evaluating the effect of in the final result of the analyses, the following equation was used:

Effect $C / c=(s+u+w+y) / 4-(t+v+x+z) / 4 E q .(1)$.

Through the use of Youden's test, it is possible to establish certainly the parameters which present higher influence in the final result of the analyses and perform a more rigorous control in the eventual variations of these parameters that may occur during a routine analysis.

In this study, our first trials were directed to find optimal chromatographic conditions. Our objective of the chromatographic method development was to achieve a peak tailing factor $<1.5$, retention time in between 1 and 2 min, along with good resolution. In 
Огляди літератури, оригінальні дослідження, погляд на проблему, випадок з практики, короткі повідомлення both equipments (Shimadzu Nexera XR UPLC system and Agilent 1260 Infinity II system), were carried out simultaneously the assays for the robustness evaluation of the chromatographic method. The results obtained in the eight runs to enalapril sample and standard solutions.

In table 3 the effects of the parameter variations in the analysis results are presented.

Table 1. Analytical parameters and variations for the robustness evaluation of HPLC method for valsartan quantitation

\begin{tabular}{|c|c|c|c|c|c|c|c|}
\hline \multicolumn{2}{|r|}{ Parameter } & \multicolumn{3}{|c|}{ Nominal condition } & \multicolumn{3}{|c|}{ Variation } \\
\hline A/a & Methanol in mobile phase & 55 & - & $\mathrm{A}$ & 45 & - & a \\
\hline $\mathrm{B} / \mathrm{b}$ & $\begin{array}{l}25 \mathrm{mM} \text { solution potassium } \\
\text { dihydrogen phosphate } \mathrm{pH} \\
7.3 \text { in mobile phase }\end{array}$ & 45 & - & B & 55 & - & $b$ \\
\hline $\mathrm{C} / \mathrm{c}$ & $\begin{array}{l}\text { pH of solution potassium } \\
\text { dihydrogen phosphate in } \\
\text { mobile phase }\end{array}$ & 7.3 & - & $\mathrm{C}$ & 7.0 & - & C \\
\hline$D / d$ & Column temperature, ${ }^{\circ} \mathrm{C}$ & 40 & - & $\mathrm{D}$ & 30 & - & $d$ \\
\hline $\mathrm{E} / \mathrm{e}$ & $\begin{array}{l}\text { Mobile phase flow rate, } \mathrm{ml} / \\
\text { min }\end{array}$ & 1.0 & - & $E$ & 0.7 & - & e \\
\hline$F / F$ & Column supplier & Zorbax C8 & - & $\mathrm{F}$ & $\begin{array}{c}\text { Grace Platinump } \\
\text { C8 EPS } \\
\end{array}$ & - & $\mathrm{f}$ \\
\hline $\mathrm{G} / \mathrm{g}$ & Chromatograph model & $\begin{array}{c}\text { Shimadzu } \\
\text { Nexera XR } \\
\text { UPLC system }\end{array}$ & - & G & $\begin{array}{c}\text { Agilent } 1260 \\
\text { Infinity II system }\end{array}$ & - & $g$ \\
\hline
\end{tabular}

Table 2. Factorial combination of the analytical parameters for robustness evaluation

\begin{tabular}{|c|c|c|c|c|c|c|c|c|}
\hline Analytical parameter & & & & tor & na & & & \\
\hline $\begin{array}{l}\text { Methanol in mobile } \\
\text { phase }\end{array}$ & $A$ & $A$ & $A$ & $A$ & $a$ & $a$ & $a$ & $a$ \\
\hline $\begin{array}{l}25 \mathrm{mM} \text { solution } \\
\text { potassium dihydrogen } \\
\text { phosphate } \mathrm{pH} 7.3 \text { in } \\
\text { mobile phase }\end{array}$ & $\mathrm{B}$ & $B$ & $b$ & $b$ & $B$ & $B$ & $\mathrm{~b}$ & $\mathrm{~b}$ \\
\hline $\begin{array}{l}\text { pH of solution } \\
\text { potassium dihydrogen } \\
\text { phosphate in mobile } \\
\text { phase }\end{array}$ & C & C & $\mathrm{C}$ & c & $\mathrm{C}$ & c & $\mathrm{C}$ & c \\
\hline Column temperature & $\mathrm{D}$ & $\mathrm{D}$ & $\mathrm{d}$ & $\mathrm{d}$ & $d$ & $d$ & $\mathrm{D}$ & $\mathrm{D}$ \\
\hline Mobile phase flow rate & $E$ & $\mathrm{e}$ & $E$ & $\mathrm{e}$ & $\mathrm{e}$ & $\mathrm{E}$ & $\mathrm{e}$ & $\mathrm{E}$ \\
\hline Column supplier & $\mathrm{F}$ & $\mathrm{f}$ & $\mathrm{f}$ & $\mathrm{F}$ & $\mathrm{F}$ & $\mathrm{f}$ & $\mathrm{f}$ & $\mathrm{F}$ \\
\hline Chromatograph model & $G$ & $g$ & $g$ & $G$ & $g$ & G & G & $g$ \\
\hline Result & $\mathrm{s}$ & $\mathrm{t}$ & $u$ & $\mathrm{v}$ & $w$ & $\mathrm{x}$ & $\mathrm{y}$ & $\mathrm{z}$ \\
\hline
\end{tabular}

Table 3. Effects of the analytical parameters in content and retention time (Rt) for valsartan HPLC quantitation

\begin{tabular}{|l|c|c|}
\hline \multicolumn{1}{|c|}{ Effect } & Content (\%) & Rt (min) \\
\hline Methanol in mobile phase & 0.13 & -0.31 \\
\hline $\begin{array}{l}\text { 25 mM solution potassium } \\
\text { dihydrogen phosphate pH 7.3 in } \\
\text { mobile phase }\end{array}$ & 0.19 & -0.39 \\
\hline $\begin{array}{l}\text { pH of solution potassium dihydrogen } \\
\text { phosphate in mobile phase }\end{array}$ & 0.18 & 0.07 \\
\hline Column temperature & -0.07 & 0.04 \\
\hline Mobile phase flow rate & -0.09 & 0.07 \\
\hline Column supplier & 0.91 & -2.04 \\
\hline Chromatograph model & -0.05 & 0.05 \\
\hline
\end{tabular}


Огляди літератури, оригінальні дослідження, погляд на проблему, випадок з практики, короткі повідомлення

By using the criteria of Youden's test, HPLC method proved to be greatly robust regarding content of valsartan, when variations in seven analytical parameters were introduced. This was done in order to make analytical scientists more successful and businesses more profitable and productive.

Conclusion. Youden's test proved to be an efficient and helpful tool for the robustness evaluation of HPLC method for assay of valsartan in pharmaceu- ticals. Therefore, Youden's test can be applied successfully for the robustness evaluation in validation process of analytical methods.

Funding. Author is grateful to the Ministry of Health of Ukraine Fund for providing scholarship for studies related to solutions for development of original combinations of antihypertensive agents, their analysis and standardization (No. 509, February 24, 2020).

\section{LIST OF LITERATURE}

1. Gupta K. R. UV-Spectrophotometric methods for estimation of valsartan in bulk and tablet dosage form / K. R. Gupta, A. R. Wadodkar, S. G. Wadodkar // Int. J. ChemTech. Res. - 2010. - Vol. 2 (2). - P. 985-989.

2. Kalaimagal A. Spectrophotometric methods for the estimation of valsartan in bulk and oral dosage form / A. Kalaimagal, S. Jerad, V. Niraimathi // Int. J. Pharm. Pharm. Sci. - 2012. - Vol. 4 (2). - P. 481-483.

3. Development and validation of new UV-spectrophotometric assay method for valsartan in pure and in formulations / R. G. Sivasankara, R. S. Venkat, S. V. M. Vardhanb, D. Ramachandrana // J. Chem. Pharm. Res. - 2013. Vol. 5 (7). - P. 229-232.

4. Simple quantitative method development and validation of valsartan in pure form and pharmaceutical dosage forms by UV spectroscopy / K. S. Nataraj, C. S. V. Ramakrishnama, G. E. Swathi [et al.] // Int. J. Pharm. Biol. Sci. - 2011. Vol. 1 (2). - P. 67-73.

5. Namrata R. P. First derivative spectrophotometric method for the simultaneous estimation of valsartan and hydrochlorthiazide in their combined dosage form / R. P. Namrata, K. P. Sejal // Int. J. Pharm. Life Sci. - 2012. Vol. 3 (7). - P. 1828-1832.

6. Sridevi R. Simultaneous spectrophotometric determination of valsartan and ezetimibe in pharmaceuticals / R. Sridevi, K. M. Badal, G. N. Sameer // Trop. J. Pharm. Res. 2011. - Vol. 10 (6). - P. 809-815.

7. Tatar S. Comparison of UV- and second derivativespectrophotometric and LC methods for the determination of Valsartan in pharmaceutical formulation / S. Tatar, S. Saglík // J. Pharm. Biomed. Anal. -2002. - Vol. 30. - P. 371-375.

8. Simultaneous determination of valsartan and hydrochlorothiazide in tablets by first-derivative ultraviolet spectrophotometry and LC / S. Eda, A. Sadi, G. Nilgun [et al.] // J. Pharm. Biomed. Anal. - 2001. - Vol. 25. - P. 1009-1013.

9. Simultaneous estimation of valsartan, amlodipine besylate and hydrochlorothiazide by first order derivative UV spectrophotometric method / M. B. Nikam, D. Harshad, A. Aniket, M. S. Kondawar // Int. J. PharmTech. Res. -2010. Vol. 2 (3). - P. 642-650.

10. Validated RP-HPLC method for the quantitative estimation of valsartan in bulk and pharmaceutical dosage forms / G. Thanusha, C. J. G. Babu, K. P. C. Basavaraj [et al.]//Int. J. ChemTech. Res. -2010. - Vol. 2 (2). - P. 1194-1198.

11. Development and validation of analytical method for the estimation of valsartan in pure and tablet dosage form by RP-HPLC method / P. V. Santosh Kumar, S. Manoran-

jan, K. Durga Prasad, M. Chandra Shekhar // Int. J. Res. Pharm. Chem. - 2011. - Vol. 1 (4). - P. 945-949.

12. Vinzuda D. U. RP-HPLC method for determination of valsartan in tablet dosage form / D. U. Vinzuda, G. U. Sailor, N. R. Sheth // Int. J. ChemTech. Res. - 2010. - Vol. 2 (3). P. 1461-1467.

13. Meghraj D. K. Precise and accurate RP-HPLC method development for quantification of valsartan in tablet dosage form / D. K. Meghraj, K. B. Saurabh // Int. J. Pharm. Sci. Drug Res. - 2012. - Vol. 4 (2). - P. 137-139.

14. Jin X. Determination of in vitro dissolution of valsartan dispersible tablets with HPLC / X. Jin, J. Pan, B. Wang // Yiyao Daobao. - 2006. - Vol. 25. - P. 473-474.

15. Simultaneous determination of fixed dose combination of nebivolol and valsartan in human plasma by liquid chromatographic-tandem mass spectrometry and its application to pharmacokinetic study / S. P. Senthamil, G. K. Veeran, U. Mandal [et al.] // J. Chromatogr. B. Analyt. Technol. Biomed. Life Sci. - 2007. - Vol. 858. - P. 143-150.

16. Fast screening method for the determination of angiotensin II receptor antagonists in human plasma by high-performance liquid chromatography with fluorimetric detection / L. Gonzalez, J. A. Lopez, R. M. Alonso, R. M. Jimenez // J. Chromatogr. A. - 2002. - Vol.949. P. 49-60.

17. Development and validation of a method for quantitative determination of valsartan in human plasma by liquid chromatography-tandem mass spectrometry / N. Koseki, H. Kawashita, H. Hara [et al.] // J. Pharm. Biomed. Anal. - 2007. - Vol. 43. - P. 1769-1774.

18. Macek J. Rapid determination of valsartan in human plasma by protein precipitation and high-performance liquid chromatography / J. Macek, J. Klima, P. Ptacek // J. Chromatogr. B. Analyt. Technol. Biomed. Life Sci. 2006. - Vol. 832. - P. 169-172.

19. The State Pharmacopeia of Ukraine in 3 vol. State Enterprise "Ukrainian Scientific Expert Pharmacopoeial Center of the Quality of Medicines" 2nd iss. - Kharkiv: State Enterprise "Ukrainian Scientific and Experimental Pharmacopoeial Center for the Quality of Medicinal Products". - 2015. - $1128 p$.

20. European Pharmacopoeia. European Pharmacopoeia. 10 edn. - 2020. - Access mode : https://www.edqm. eu/en/european_pharmacopoeia_10th_edition.

21. ICH Q2 (R1). Validation of analytical procedures. Text and methodology : Int. Conf. Harmoniz. - Geneva, 2005. - p. 1-17. 
Огляди літератури, оригінальні дослідження, погляд на

22. Efficient Validated HPLC/UV Method for Determination of Valsartan and Atenolol in Dosage Form And In Vitro Dissolution Studies / M. Piponski, K. Peleshok, L. Logoyda [et al.] // Biointerface Res. Appl. Chem. - 2020. Vol. 10 (6). - P. 6669-6675.

23. Epshtein N. A. Investigation of robustness at validation of HPLC and UPLC methods: a modern approach including risk analysis / N. A. Epshtein, V. L. Sevastianova, A. I. Koroleva // Drug Develop. \& Registr. - 2018. - Vol. 1 (22). P. 96-109.

24. Steiner Y. E. H. Statistical manual of the associa- блему, випадок з практики, короткі повідомлення tion of official analytical chemists / Y. E. H. Steiner. - The Association of Official Analytical Chemists ed. Arlington, 1975. - P. 33-36; 70-71; 82-83.

25. da Costa Cesar I. Robustness evaluation of the chromatographic method for the quantitation of lumefantrine using Youden's test / da Costa Cesar I., G. A. Pianetti // Braz. J. Pharm. Sci. - 2009. - Vol. 45. - P. 235-240.

26. Karageorgou E. Youden test application in robustness assays during method validation / E. Karageorgou, V. Samanidou // J. Chromatogr. A. - 2014. - Vol. 1353. P. 131-139.

\section{REFERENCES}

1. Gupta, K.R., Wadodkar, A.R., \& Wadodkar, S.G. (2010). UV-Spectrophotometric methods for estimation of valsartan in bulk and tablet dosage form. Int. J. ChemTech. Res., 2 (2). 985-989.

2. Kalaimagal, A., Jerad, S., \& Niraimathi, V. (2012). Spectrophotometric methods for the estimation of valsartan in bulk and oral dosage form. Int. J. Pharm. Pharm. Sci., 4 (2). 481-483.

3. Sivasankara, R.G., Venkat, R.S., Vardhanb, S.V.M., \& Ramachandrana, D. (2013). Development and validation of new UV-spectrophotometric assay method for valsartan in pure and in formulations. J. Chem. Pharm. Res., 5 (7), 229232.

4. Nataraj, K.S., Ramakrishnama, C.S.V., Swathi, G.E., Saigeethika, S., \& Ramanjineyulu, K. (2011). Simple quantitative method development and validation of valsartan in pure form and pharmaceutical dosage forms by UV spectroscopy. Int. J. Pharm. Biol. Sci., 1 (2). 67-73.

5. Namrata, R.P., \& Sejal, K.P. (2012). First derivative spectrophotometric method for the simultaneous estimation of valsartan and hydrochlorthiazide in their combined dosage form. Int. J. Pharm. Life Sci., 3 (7), 1828-1832.

6. Sridevi, R., Badal, K.M., \& Sameer, G.N. (2011). Simultaneous spectrophotometric determination of valsartan and ezetimibe in pharmaceuticals. Trop. J. Pharm. Res., 10 (6), 809-815.

7. Tatar, S., \& Saglík, S. (2002). Comparison of UV- and second derivative- spectrophotometric and LC methods for the determination of Valsartan in pharmaceutical formulation. J. Pharm. Biomed. Anal., 30, 371-375.

8. Eda, S., Sadi, A., Nilgun, G.G., Sibel, O., \& Zuhre, S. (2001). Simultaneous determination of valsartan and hydrochlorothiazide in tablets by first-derivative ultraviolet spectrophotometry and LC. J. Pharm. Biomed. Anal., 25, 1009-1013.

9. Nikam, M.B., Harshad, D., Aniket, A., \& Kondawar, M.S. (2010). Simultaneous estimation of valsartan, amlodipine besylate and hydrochlorothiazide by first order derivative UV spectrophotometric method. Int. J. Pharm. Technol., 2 (3), 642-650.

10. Thanusha, G., Babu, C.J.G., Basavaraj, K.P.C., Panditi, V.R., \& Sharadha, C. (2010). Validated RP-HPLC method for the quantitative estimation of valsartan in bulk and pharmaceutical dosage forms. Int. J. ChemTech. Res., 2 (2), 1194-1198.

11. Santosh Kumar, P.V., Manoranjan, S., Durga Prasad, K., \& Chandra Shekhar, M. (2011). Development and

validation of analytical method for the estimation of valsartan in pure and tablet dosage form by RP-HPLC method. Int. J. Res. Pharm. Chem., 1 (4), 945-949.

12. Vinzuda, D.U., Sailor, G.U., \& Sheth, N.R. (2010) RP-HPLC method for determination of valsartan in tablet dosage form. Int. J. ChemTech. Res., 2 (3), 1461-1467.

13. Meghraj, D.K., \& Saurabh, K.B. (2012). Precise and accurate RP-HPLC method development for quantification of valsartan in tablet dosage form. Int. J. Pharm. Sci. Drug Res., 4 (2), 137-139.

14. Jin, X., Pan, J., \& Wang, B. (2006). Determination of in vitro dissolution of valsartan dispersible tablets with HPLC. Yiyao Daobao, 25, 473-474.

15. Senthamil, S.P, Veeran, G.K., Mandal, U., Solomon, W.D., \& Pal, T.K. (2007). Simultaneous determination of fixed dose combination of nebivolol and valsartan in human plasma by liquid chromatographic-tandem mass spectrometry and its application to pharmacokinetic study. J. Chromatogr. B. Analyt. Technol. Biomed. Life Sci., 858, 143-50.

16. Gonzalez, L., Lopez, J.A., Alonso, R.M., \& Jimenez, R.M. (2002). Fast screening method for the determination of angiotensin ii receptor antagonists in human plasma by high-performance liquid chromatography with fluorimetric detection. J. Chromatogr. A., 949, 49-60.

17. Koseki, N., Kawashita, H., Hara, H., Niina, M., Tanaka, M., Kawai, R., ... \& Masuda, N. (2007). Development and validation of a method for quantitative determination of valsartan in human plasma by liquid chromatographytandem mass spectrometry. J. Pharm. Biomed. Anal., 43. 1769-1774.

18. Macek, J., Klima, J., \& Ptacek, P. (2006). Rapid determination of valsartan in human plasma by protein precipitation and high-performance liquid chromatography. J. Chromatogr. B. Analyt. Technol. Biomed. Life Sci., 832. 169-172.

19. (2015). The State Pharmacopeia of Ukraine in $3 \mathrm{vol}$. State Enterprise "Ukrainian Scientific Expert Pharmacopoeial Center of the Quality of Medicines" 2nd iss. Kharkiv: State Enterprise "Ukrainian Scientific and Experimental Pharmacopoeial Center for the Quality of Medicinal Products".

20. (2020). European Pharmacopoeia. European Pharmacopoeia. 10 edn. Retrieved from: https://www.edqm. eu/en/european_pharmacopoeia_10th_edition.

21. ICH Q2 (R1). (2005). Validation of analytical procedures. Text and methodology: Int. Conf. Harmoniz. Geneva.

22. Piponski, M., Peleshok, K., Logoyda, L., Kravchuk, L., Piatnochka, V., \& Zakharchuk, U. (2020). Efficient validated HPLC/UV method for determination of Valsar- 
Огляди літератури, оригінальні дослідження, погляд на проблему, випадок з практики, короткі повідомлення tan and Atenolol in dosage form and in vitro dissolution studies. Biointerface Res. Appl. Chem., 10 (6), 6669-6675.

23. Epshtein, N.A., Sevastianova, V.L., \& Koroleva A.I. (2018). Investigation of robustness at validation of HPLC and UPLC methods: a modern approach including risk analysis. Drug Develop. \& Registr., 1 (22), 96-109.

24. Steiner, Y.E.H. (1975). Statistical manual of the association of official analytical chemists. The Association of Official Analytical Chemists ed. Arlington.

25. da Costa Cesar I., \& Pianetti G.A. (2009). Robustness evaluation of the chromatographic method for the quantitation of lumefantrine using Youden's test. Braz. J. Pharm. Sci., 45, 235-240.

26. Karageorgou, E., \& Samanidou, V. (2014). Youden test application in robustness assays during method validation. J. Chromatogr. A., 1353, 131-139.

\section{ВИВЧЕННЯ РОБАСНОСТІ ХРОМАТОГРАФІЧНОГО ВИЗНАЧЕННЯ ВАЛСАРТАНУ В ЛІКАРСЬКИХ ЗАСОБАХ}

\section{๑К. Є. Пелешок, О. М. Дутчак, Фатма Абделмалек Мохамед}

Тернопільський національний медичний університет імені І. Я. Горбачевського мОз України

РЕзЮМЕ. Робасність аналітичної процедури - це показник її здатності залишатись незмінною через незначні, але навмисні зміни параметрів методу, який забезпечує вказівку на його надійність під час звичайного використання.

Мета - вивчити робасність хроматографічного визначення валсартану в таблетках з використанням тесту Юдена.

Матеріал і методи. Ефективна оцінка надійності аналітичних методів за допомогою тесту Юдена проведена шляхом розробки експерименту, який включає сім аналітичних параметрів, об'єднаних у восьми тестах. У дослідженнях ми оцінювали надійність хроматографічного методу для кількісного визначення валсартану в таблетках з використанням тесту Юдена.

Результати. Підхід до експериментального проектування (дизайн експерименту) - це метод одночасного дослідження впливу кількох факторів на робасність методу за допомогою певного плану (матриці) експериментів. Використовуючи критерії випробування Юдена, метод ВЕРХ показав високу надійність щодо вмісту валсартану при введенні варіації семи аналітичних параметрів. Це потрібно для того, щоб зробити вчених-аналітиків більш успішними, а підприємства - більш прибутковими та продуктивними.

Висновки. Тест Юдена виявився ефективним і корисним інструментом для оцінки робасності для аналізу валсартану методом ВЕРХ. Тест Юдена можна успішно застосувати для оцінки робасності в процесі валідації аналітичних методик.

КлючовІ СлОВА: валсартан; високоефективна рідинна хроматографія; робасність; кількісний аналіз; тест Юдена.

\section{ИЗУЧЕНИЕ РОБАСТНОСТИ ХРОМАТОГРАФИЧЕСКОГО ОПРЕДЕЛЕНИЯ ВАЛСАРТАНА В ЛЕКАРСТВЕННЫХ СРЕДСТВАХ}

\section{๑Е. Е. Пелешок, О. М. Дутчак, Фатма Абделмалек Мохамед}

Тернопольский национальный медицинский университет имени И. Я. Горбачевского МОз Украины

РЕЗЮМЕ. Робастность аналитической процедуры - это показатель ее способности оставаться неизменной из-за незначительного, но умышленного изменения параметров метода, который обеспечивает указание на его надежность во время обычного использования.

Цель - изучить робастность хроматографического определения валсартана в таблетках с использованием теста Юдена.

Материал и методы. Эффективной является оценка надежности аналитических методов с помощью теста Юдена путем разработки эксперимента, который включает семь аналитических параметров, объединенных в восьми тестах. Во время исследований была оценена надежность хроматографического метода для количественного определения валсартана в таблетках с использованием теста Юдена.

Результаты. Подход к экспериментальному проектированию (дизайн эксперимента) - это метод одновременного исследования влияния нескольких факторов на робастность метода с помощью определенного плана (матрицы) экспериментов. При применении критериев испытания Юдена метод высокоэффективной жидкостной хроматографии показал высокую надежность в отношении содержания валсартана в условиях введения вариации семи аналитических параметров. Это необходимо, чтобы сделать ученых-аналитиков успешнее, а предприятия - более прибыльными и продуктивными.

Выводы. Тест Юдена оказался эффективным и полезным инструментом для оценки робастности во время анализа валсартана методом высокоэффективной жидкостной хроматографии. Его можно успешно применять для оценки робастности в процессе валидации аналитических методик.

КЛЮЧЕВЫЕ СЛОВА: валсартан; высокоэффективная жидкостная хроматография; робастность; количественный анализ; тест Юдена.

Отримано 01.08.2020 